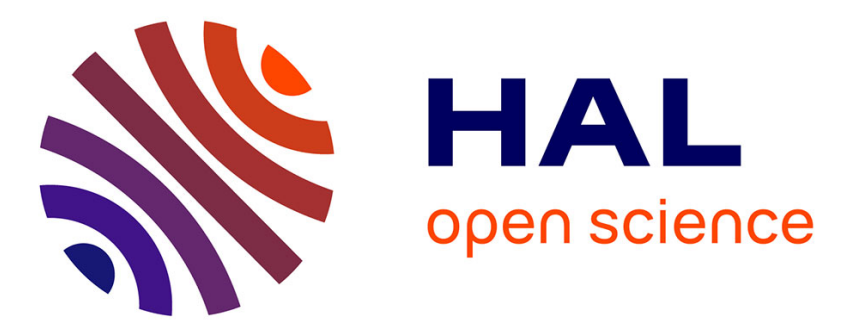

\title{
Roles of the particulate phases in pharmaceuticals spatio-temporal dynamics in a peri-urban stream
}

Lauriane Ledieu, Anaëlle Simonneau, Olivier Cerdan, Laëtitia Fougère, Emilie Destandau, Thomas Thiebault, Fatima Laggoun-Défarge

\section{- To cite this version:}

Lauriane Ledieu, Anaëlle Simonneau, Olivier Cerdan, Laëtitia Fougère, Emilie Destandau, et al.. Roles of the particulate phases in pharmaceuticals spatio-temporal dynamics in a peri-urban stream. EGU General Assembly 2020, May 2020, Online, France. 10.5194/egusphere-egu2020-20122 . hal03554403

\section{HAL Id: hal-03554403 \\ https://hal.science/hal-03554403}

Submitted on 4 Feb 2022

HAL is a multi-disciplinary open access archive for the deposit and dissemination of scientific research documents, whether they are published or not. The documents may come from teaching and research institutions in France or abroad, or from public or private research centers.
L'archive ouverte pluridisciplinaire HAL, est destinée au dépôt et à la diffusion de documents scientifiques de niveau recherche, publiés ou non, émanant des établissements d'enseignement et de recherche français ou étrangers, des laboratoires publics ou privés.

\section{(c)(1)}

Distributed under a Creative Commons Attribution| 4.0 International License 
EGU2020-20122

https://doi.org/10.5194/egusphere-egu2020-20122

EGU General Assembly 2020

(c) Author(s) 2022. This work is distributed under

the Creative Commons Attribution 4.0 License.

\title{
Roles of the particulate phases in pharmaceuticals spatio-temporal dynamics in a peri-urban stream
}

\author{
Lauriane Ledieu ${ }^{1}$, Anaëlle Simonneau ${ }^{1}$, Olivier Cerdan ${ }^{2}$, Laëtitia Fougère ${ }^{3}$, Emilie Destandau ${ }^{3}$, \\ Thomas Thiebault ${ }^{4}$, and Fatima Laggoun ${ }^{1}$ \\ ${ }^{1}$ Univ. Orléans, CNRS, BRGM, ISTO, UMR 7327, F-45071, Orléans, France (lauriane.ledieu@cnrs-orleans.fr) \\ ${ }^{2}$ BRGM, 3 avenue Claude Guillemin, 45060 Orléans, France \\ ${ }^{3}$ Univ Orleans, CNRS, ICOA, UMR 7311, 45067 Orleans, France \\ ${ }^{4}$ EPHE, PSL University, UMR 7619 METIS (SU, CNRS, EPHE), 4 Place Jussieu, F-75005, Paris, France
}

Wastewaters are highly contaminated waters by anthropogenic compounds. To limit the propagation of these contaminants in water bodies and allow safe reuse of this resource, sewage treatment plants were developed. For the last few decades, many studies evidenced the partial cleaning efficiency of these systems. Many compounds, such as pharmaceuticals, are therefore designated as emerging contaminants. Most of the studies investigated sewage treatment plants releasing rates, but spatial and temporal behaviours of pharmaceuticals in natural environments received less attention. In this study, 27 pharmaceuticals were investigated into both water, bedload sediments and suspended particles from a small tributary of the Loire River: a peri-urban stream named Egoutier (Loiret, France). The catchment area of the Egoutier is characterized by an upstream/downstream anthropogenic gradient and the presence of two sewage stations whose effluents are released in the watercourse: one coming from the Central Army Pharmacy, a second one draining a psychiatric hospital and a last one defining a bad connection of the pluvial piping system. Only 13 pharmaceuticals were found in our samples. Cationic compounds, such as doxepin, metoprolol, atenolol, codeine and trimethoprim, were mostly adsorbed on mineral phases, except tramadol appearing mostly associated with organic matter, like the anionic and neutral compounds, such as sulfamethoxazole, ibuprofen, diclofenac, acetaminophen, diazepam, carbamazepine and oxazepine. High spatial and temporal variabilities were observed. Bed-load geochemistry fluctuations appear linked to the sedimentary dynamic from both suspended particles and organic matter. In the suspended particles fraction, pharmaceuticals contents seem to be driven by grain-size distribution. Variations in pharmaceutical inputs and low half-life of some molecules also have an influence on both particulate fractions contents. In this way, some compounds highly biodegradable, such as acetaminophen, are accumulated near to their emission zones, while other molecules highly transported in suspended particles, for example diazepam, are transported over the stream and mostly accumulated in bed-load sediments during dry periods. On the contrary, compounds adsorb on coarser particles, such as trimethoprim, have higher propagation distances during humid periods. Some molecules could be used as sourcing markers. Indeed, codeine is for example exclusively released by the psychiatric hospital. In the same way, sulfamethoxazole, ibuprofen, tramadol and codeine are specifically emitted from the 
Central Army Pharmacy and the psychiatric hospital. This study improve the understanding of pharmaceuticals adsorption, dispersion and accumulation in receiving environments. Moreover, it allow better distinction between domestic consumption releases and hospital and/or pharmacy facilities impacts. 